$\left.\begin{array}{c}\text { Sournals } \\ \text { ONTERNATIONAL JOURNAL OF } \\ \text { ORGANIZATIONAL LEADERSHIP }\end{array}\right) \begin{gathered}\text { INDUSTRIAL } \\ \text { MANAGEMENT } \\ \text { INSTITUTE }\end{gathered}$

\title{
The effect of organizational loads on work stress, emotional commitment, and turnover intention
}

\author{
Serhat ERAT ${ }^{1}$, Hakan KITAPÇI ${ }^{2}$, Pınar ÇÖMEZ ${ }^{3 *}$ \\ ${ }^{1}$ Gebze Technical University, Kocaeli, Turkey \\ ${ }^{2}$ Gebze Technical University, Faculty of Business Administration, Kocaeli, Turkey \\ ${ }^{3}$ Adana Science and Technology University Faculty of Business, Turkey
}

\begin{tabular}{|c|c|}
\hline & ABSTraCt \\
\hline \multicolumn{2}{|l|}{ Keywords: } \\
\hline $\begin{array}{l}\text { Responsibility Load, } \\
\text { Workload, Emotional } \\
\text { Commitment, Turnover } \\
\text { Intention, Work Stress }\end{array}$ & $\begin{array}{l}\text { In the success of institutions, the peace and quality of the business life of human resources } \\
\text { play an important role. The organizational load on employees can affect both individual } \\
\text { and organizational stress, their turnover intention, and emotional commitment. Therefore, } \\
\text { institutional stress and commitment have become the subject of many studies. In this study, }\end{array}$ \\
\hline $\begin{array}{l}\text { Received } \\
08 \text { May } 2016\end{array}$ & $\begin{array}{l}\text { we investigate the effects of responsibility load and workload on work stress, emotional } \\
\text { commitment, and turnover intention, using a sample that consists of academics employed in }\end{array}$ \\
\hline $\begin{array}{l}\text { Received in revised form } \\
\text { 10 January } 2017\end{array}$ & $\begin{array}{l}\text { state universities in Turkey. Data analyzed in this study were collected via questionnaires } \\
\text { from the academics }(\mathrm{n}=1043) \text {. The results indicated that workload and responsibility load }\end{array}$ \\
\hline $\begin{array}{l}\text { Accepted } \\
11 \text { January } 2017\end{array}$ & $\begin{array}{l}\text { affect work stress; work load and responsibility load affect emotional commitment; and } \\
\text { work load affects turnover intention, while responsibility load has no effect on it. }\end{array}$ \\
\hline
\end{tabular}

Correspondence:

pcomez@gmail.com

(C)AIMI Journals

Human resource practices are a central issue for the survival and success of an organization in today's competitive environment. Having skilled employees is one source of competitive advantage for an organization. The ability to maintain this advantage depends upon retaining skilled and highly qualified employees. Stress in the workplace is a widespread problem and has become a major public health issue due to its negative effects on both physiological and mental health (Lee, Joo, \& Choi, 2013). In addition, workplace stress is a costly phenomenon for organizations and it contributes to expensive voluntary turnover (O'Neill \& Davis, 2011). Matteson and Ivancevich (1987) discussed how organizations can assist in combating stress in 
ways that benefit both the employees involved and the organization itself. Work stress can cause various negative reactions including tension and conflict in the workplace as well as absences (Lambert, Hogan, \& Griffin, 2007). Furthermore, excess workload increases work stress, which in turn decreases the level of commitment to the organization (Yaprak, 2009). Employee work stress, turnover intention, and emotional commitment are affected by responsibility load (Kirmeyer \& Dougherty, 1988). In particular, in knowledge-intensive research, commitment to the business has become paramount (Kwon, Bar, \& Lawler, 2010).

Compared with previous years, the recent number of universities and students in Turkey has increased significantly. However, the number of academics has not increased at the same rate. This results in the academic staff of universities facing more responsibilities such as more students, more courses, and more administrative work; and, thus, academic staff are exposed to the effects of organizational loads, work stress, emotional commitment, and turnover intention. The reason for our choice of the educational sector for this study is that academicians are continuously exposed to work stress (Sigler \& Wilson, 1988).

Despite previous theoretical literature and empirical studies, there is still a lack of research focused on the turnover intention between stress, responsibility load, workload, and emotional commitment. Some workload factors most influential to the occupational workload in a manmachine system have been studied (Adams, 1988; Hancock, 1989; Jung \& Jung, 2001; Sanders \& McCormick, 1987). Stress at work is considered as a pervasive and multifaceted phenomenon (Lazarus 1993) and it is expensive for organizations since it contributes to highcost voluntary turnover (Villanueva \& Djurkovic, 2009).

Responsibility load has important implications for employee work stress, turnover intention, and emotional commitment (Kirmeyer \& Dougherty, 1988). The existing literature reports that commitment is invariably and negatively related to turnover and intent to leave a job (Arnold \& Feldman, 1982; Hollenbeck \& Williams, 1986; Tett \& Meyer, 1993). Meyer and Herscovitch's (2001) study explains commitment with differing points of view and dimensions. They also demonstrate a model in helping to understand existing research findings.

\section{The Literature Review}

\section{Relationship between Workload and Responsibility Load}

The various pressures that impact the performance and reactions of employees are called workload (Weiner, 1982). Further, the workload is the individuals' perception that the amount of work they have to do is beyond normal (Cedoline, 1982). On the other hand, a workload that does not prevent an employee from administering the system in a safe and effective way is considered acceptable (Jung \& Jung, 2001).

In this paper, we consider Britt's (1999) definition of responsibility as "an individual's involvement with various work-related events and their outcomes because the consequences have implications for their identity". Previous literature has established that "the amount of responsibility an individual feels on any given occasion is a direct function of the strength of the links between the elements and the importance of the elements to the individual" (Britt, 1999).

Responsibility load occurs when one is faced with too many work events to accomplish in the time available (Kirmeyer \& Dougherty, 1988). Accordingly, responsibility load is shaped 
by the employee's title and work content. Tasks that require more knowledge, decisionmaking, and skill carry a higher responsibility load (Brennan \& Spencer, 2010). New administrative candidates have very little decision-making responsibility, which benefits relatively fewer people while they learn tasks that require limited skill and job components (Fried, Grant, Levi, Hadani, \& Slowik, 2007). As the role of an individual increases in an organization their responsibility load also increases. Randall (2006) stated that a heavy workload resulting from increasing responsibilities such as educating and mentoring can become a problem for academics. With reference to Yıldırım, Ünal and Çelik (2011), academics have an excessive workload and numerous responsibility loads.

\section{Relationship between Workload and Work Stress}

Stress is a reaction or internal condition that occurs toward anything that is perceived as a threat, whether in a true or imaginary way, or a conscious or unconscious way (Steers, 1981). In addition, stress is a dynamic condition where an individual is exposed to an opportunity, pressure, or demand that is related to something that she/he deserves, and the result is accepted as both uncertain and important. Some organizational and environmental factors in the workplace such as a heavy workload (Nasurdin, Ramayah, \& Kumaresan, 2005) cause work stress.

It has been observed that employees in the education sector have more workload and more work stress (Tel \& Köksalan, 2008) than employees working in other sectors (Chan, Lai, Ko, \& Boey, 2000). Thus, several studies have examined stress among the employees of the educational sector (Boyle, Borg, Falzon, \& Baglioni, 1995; Paulse, 2005).

Excessive or insufficient workload and time pressures cause work stress significantly more than other factors. In this sense, the various pressures that affect the performance and reactions of employees are called workload (Weiner, 1982). Research has shown that academic staff is easily exposed to excessive workload which results in work stress (Chan, Lai, Ko, \& Boey, 2000).

\section{Relationship between Responsibility Load and Work Stress}

Employees with more responsibility feel more stress than other employees within an organization (Greenberg \& Baron, 1995). According to Kreitner and Kinicki (1998), the sources of stress directly depend on the individual's tasks and responsibilities. The increased workload and the number of subordinates create the responsibility load of managerial employees (Markham, 1989). Responsibility with regard to other employees increases stress for managerial employees (Paşa, 2007). In Maslach, Schaufeli, and Leiter's (2001) opinion, those with more advanced educational backgrounds have a higher inclination towards taking on additional responsibility when compared with those with lower educational backgrounds, which in turn leads to stress.

\section{Relationship between Workload and Emotional Commitment}

Organizational commitment is described as a psychological condition (Meyer \& Allen, 1991) that causes the strong feeling of an employee to remain with an organization and affects his/her belief in the aims and goals of the organization. According to Guay et al. (2015), there are two 
explanations for the dispositional basis of organizational commitment in the literature. The first one concentrates on the "direct" effects of personality on how people tend to feel about their organization. The second suggests an "indirect" effect of personality on how people act in their organization based on the quality of the social exchange relations in their organization. Positive emotional attachment to the organization is conducive to improved employee to work-life balance and decreased inter-role conflicts, which leads to more supportive family and work environments (Moon, Hur, Ko, Kim, \& Yoon, 2014).

An employee with an emotional commitment is happy to be a member of the organization and does not consider resigning, since she/he thinks of herself/himself as a part of the organization (Meyer \& Herscovitch, 2001). Previous studies have found that high emotional commitment is expected from employees that are followed by normative commitment and continuance commitment (Brown, 2003). Meyer, Stanley, Herscovitch, and Topolnytsky (2002) found that emotional commitment has the strongest relationship with both individual and organizational variables much more than the other types of commitment (normative and continuance commitment). Therefore, the emotional commitment aspect of organizational commitment is addressed in this study.

Stevens, Beyer, and Trice (1978) determined that there is a negative relationship between workload and organizational commitment. In addition, Meyer and Allen (1997) stated that workload has a negative effect on the emotional commitment of employees. Maxwell and Steele (2003) proposed that the organizational commitment of administrators would be positively affected when their responsibility load and workload are stable and they found a negative relationship between workload and organizational commitment.

\section{Relationship between Responsibility Load and Emotional Commitment}

The presence of responsibility and autonomy in the workplace has an effect on the organizational commitment of an employee (Bayram, 2005). Chow (1994) stated that a high level of commitment requires more responsibility. In addition, Meyer and Allen (1991) claimed that there is a relationship between organizational commitment and the level of responsibility of the work. Kaya and Selçuk (2007) demonstrated a negative relationship between emotional commitment and the individual's responsibility.

\section{Relationship between Workload and Turnover Intention}

Turnover intention is the deliberate and conscious intention of an individual to resign from a job (Egan, Yang \& Bartlett, 2004; Tett \& Meyer, 1993). Workload directly affects theturnover intention of an employee (Jones, Chonko, Rangarajan, \& Roberts, 2007). If an employee feels self-secure in his job, the workload is considered acceptable (Jung \& Jung, 2001). Ünalan, Çetinkaya, Özyurt, and Kayabaşı (2006) found that workload inequity causes employee turnover intention.

\section{Relationship between Responsibility Load and Turnover Intention}

Daniels, Harris, and Briner (2004) stated that responsibility is a precursor of turnover intention and has a direct effect on turnover intention. Similarly, Liou and Cheng (2010) and Torka, 
Schyns, and Looise (2010) found that there is a positive correlation between low responsibility and turnover intention.

\section{The Study}

The research model used in this study is shown in Figure 1.

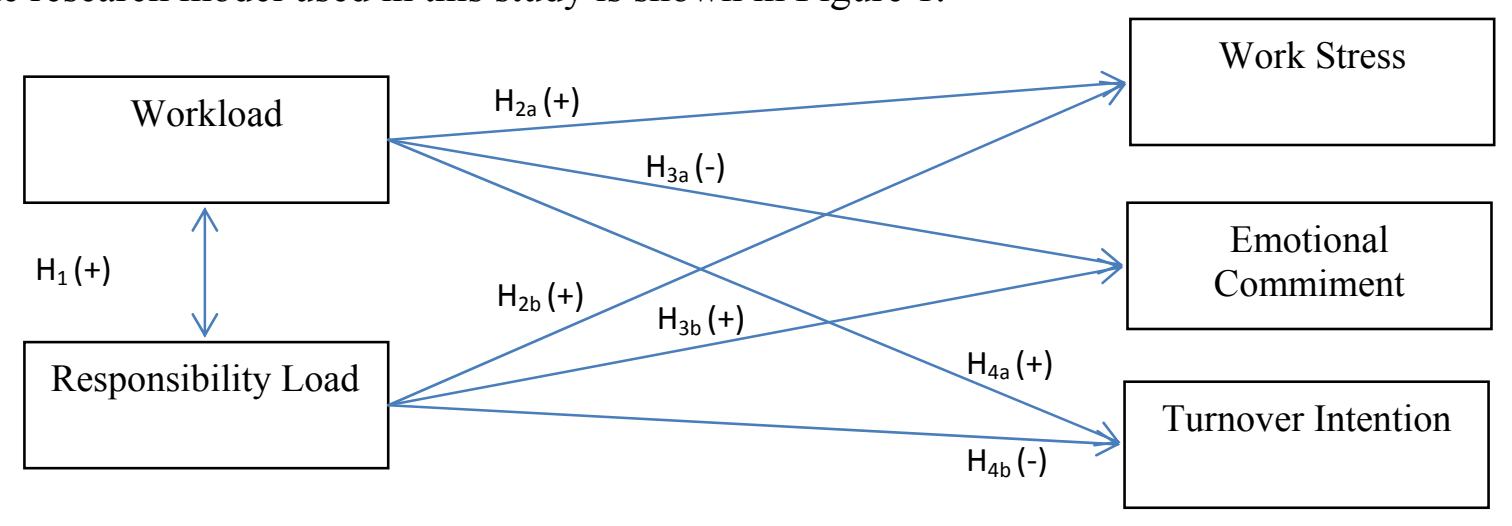

Figure 1: Research model

\section{Research Hypotheses}

The following research hypotheses guided the study.

$\mathbf{H}_{1}$ : Workload positively relates to responsibility load.

$\mathbf{H}_{2 \mathbf{a}}$ : Workload positively relates to work stress.

$\mathbf{H}_{2 \mathrm{~b}}$ : Responsibility load positively relates to work stress.

H3a: Workload negatively relates to emotional commitment.

$\mathbf{H}_{3 \mathbf{b}}$ : Responsibility load negatively relates to emotional commitment.

$\mathbf{H}_{4 \mathbf{a}}$ : Workload positively relates to turnover intention.

$\mathbf{H}_{4 \mathbf{b}}$ : Responsibility load negatively relates to turnover intention.

\section{Method}

\section{Participants}

The participants of the present study consisted of the academicians in state universities in Turkey. For our research, a survey was emailed to the 6109 addresses of academic staff, as listed on the internet, requesting their participation. However, 892 were returned to us because of errors in the addresses or system. The study lasted for a month; the survey reached 5217 academicians and we received 1043 responses. The sampling method is preferred by many researchers in terms of homogeneity (Calder, Philips,\& Tybout, 1981). Further, the rate of return of the surveys was $19.9 \%$, which is considered acceptable for internet email surveys (Schonlau, Fricker, \& Elliott, 2002) but is lower than what is considered acceptable for other types of surveys (Sax, Gilmartin, \& Bryant, 2003). Regarding the demographic characteristics of the participants, the total number of academic staff members included in our survey was 1043. Other features included gender (62.1\% female, 37.9\% male), age (24\% between $27-31$ years, $22.5 \%$ between $32-36$ years, and $53,5 \%$ over 41 years), academic rank (466 (45\%) assistant professors and 577 (55\%) lecturers), and tenure status (382 (36.6\%) untenured and $661(63.4 \%)$ tenured). 


\section{Measures}

To measure the workload, we took advantage of a workload scale of eight questions, developed by Lim and Teo (1999) in which sample items contained "I often have to take work home". Responsibility load was assessed using the scale developed by Erat (2012) in which sample items included "My responsibilities, resulting from laws and regulations related to my job are very intensive". We used the scale developed by House and Rizzo (1972) to measure stress in which sample items contained "I have high tension while I am working". The emotional commitment was measured with seven items adopted from Meyer and Allen (1997) wherein sample items included "I will be pleased to work in this university for the rest of my career". We used the five-item turnover intention scale adopted from Bluedorn (1982).

\section{Results}

\section{Data Analysis}

Items were rated on a 5-point Likert scale ranging from $1=$ strongly disagree to $5=$ strongly agree. The SPSS program was used to determine factor structure and to analyze the relationships among variables and test hypotheses.

Table 1

Results of the Varimax Rotated Exploratory Factor Analysis

\begin{tabular}{|c|c|c|c|c|c|}
\hline I often hav eto take work home. & 0.84 & & & & \\
\hline I cannot make time for my family due to my workload. & 0.83 & & & & \\
\hline I cannot make time for my social life dueto my workload. & 0.82 & & & & \\
\hline I have to work to complete projects, and work until late in the night and on weekends. & 0.77 & & & & \\
\hline I have to do work that is not in the description of the task. & 0.72 & & & & \\
\hline I have to do much more work than I am able, due to exessive workload. & 0.69 & & & & \\
\hline I am always anxious that I cannot complete projects and work on time. & 0.67 & & & & \\
\hline I have time pressure (to complete work on time). & 0.57 & & & & \\
\hline I have high tension while I am working. & & 0.83 & & & \\
\hline I have problems such as anxiety due to my work. & & 0.80 & & & \\
\hline If I worked in another job, my health could be better. & & 0.76 & & & \\
\hline I have difficulty sleeping because of problems related to work. & & 0.76 & & & \\
\hline I keep work-related problems in my mind outside of work. & & 0.74 & & & \\
\hline The work I do affects my health quite a great deal. & & 0.73 & & & \\
\hline I feel anxious before work meetings in my university. & & 0.72 & & & \\
\hline I am thinking of resigning from this university. & & & 0.83 & & \\
\hline I hope to resign from this university in the next term. & & & 0.83 & & \\
\hline I prefer to work in this university until my retirement. & & & 0.82 & & \\
\hline I will be pleased to work in this university for the rest of my career. & & & 0.80 & & \\
\hline I have an intention to resign from this university in the next few years. & & & 0.76 & & \\
\hline My responsibilities resulting from laws and regulations related to my job are very intensive. & & & & 0.87 & \\
\hline My authorization and decision-making responsibilities related to my job, are very intensive. & & & & 0.84 & \\
\hline My observation, control, and planning responsibilities related to my job are very high. & & & & 0.76 & \\
\hline My financial responsibilities related to my job are very intensive. & & & & 0.75 & \\
\hline My communication and coordination responsibilities related to my job are very intensive. & & & & 0.70 & \\
\hline I will be pleased to work in this university for the rest of my career. & & & & & 0.80 \\
\hline I feel as if the problems of the university are my own. & & & & & 0.77 \\
\hline I do not feel any emotional commitment toward this university. & & & & & 0.75 \\
\hline This university has so much individual importance for me. & & & & & 0.47 \\
\hline
\end{tabular}

Notes. Total variances explained: $66.8 \%, 1=$ workload, $2=$ stress, $3=$ turnover intention, $4=$ responsibility load, $5=$ emotional commitment. 
Expressions related to workload, responsibility load, work stress, emotional commitment, and turnover intention were subjected to a varimax rotated exploratory factor analysis to provide data in a more meaningful and summarized format. According to the findings, all of the perceptions were loaded and separated into their factors in an expected way. In addition, responsibility load, workload, work stress, emotional commitment, and turnover intention were each separated into single factors.

The results of the varimax rotated exploratory factor analysis are given in Table 1.

The reliability coefficients of the variables were calculated as $0.91,0.87,0.92,0.78$, and 0.90 , respectively. Cronbach's alpha values were above the expected value of 0.60 (Nunually, 1978). Thus, it can be stated that the scales are reliable.

The mean, standard deviation (SD), and Cronbach's alpha value for each of the scales in the conducted correlation analysis are presented in Table 2.

Table 2

Results ofDescriptive Statistics of the Variables (Mean, SD, and Cronbach's Alpha) and Correlation Analysis

\begin{tabular}{|c|c|c|c|c|c|c|c|c|}
\hline & & Mean & SD & Cr. Alpha & 1 & 2 & 3 & 4 \\
\hline 1 & Workload & 3.42 & 0.96 & 0.91 & & & & \\
\hline 2 & Responsibility Load & 2.88 & 0.88 & 0.87 & $0.35(* *)$ & & & \\
\hline 3 & Work stress & 3.02 & 1.02 & 0.92 & $0.54(* *)$ & $0.26(* *)$ & & \\
\hline 4 & Emotional commitment & 3.27 & 0.95 & 0.78 & $-0.14(* *)$ & $0.06(*)$ & $-0.27(* *)$ & \\
\hline 5 & Turnover intention & 2.81 & 1.05 & 0.90 & $0.15(* *)$ & 0.053 & $0.31(* *)$ & $-0.55(* *)$ \\
\hline
\end{tabular}

Correlation analysis shows that workload had a negative relationship with emotional commitment and a positive relationship with the other variables. Further, although responsibility load also had a positive relationship with stress and emotional commitment, it did not have any correlation with turnover intention.

The results, regarding the hypothesis made in the regression analysis, are given in Table 3.

Table 3

Multiple Regression Analysis for Testing the Hypotheses

\begin{tabular}{|c|c|c|c|c|c|c|c|}
\hline & & \multicolumn{2}{|c|}{$\begin{array}{l}\text { MODEL } 1 \\
\text { Work Stress }\end{array}$} & \multicolumn{2}{|c|}{$\begin{array}{c}\text { MODEL 2 } \\
\text { Emotional Commitment }\end{array}$} & \multicolumn{2}{|c|}{$\begin{array}{c}\text { MODEL } 3 \\
\text { Turnover Intention }\end{array}$} \\
\hline & & $\beta$ & $\mathrm{t}$ & $\beta$ & $\mathrm{t}$ & $\beta$ & $\mathrm{t}$ \\
\hline Workload & & 0.51 & $18.51^{*}$ & -0.19 & $-6.04 *$ & 0.15 & $4.76^{*}$ \\
\hline \multirow[t]{4}{*}{ Responsibility Load } & & 0.08 & $3.02 *$ & 0.13 & $4.24 *$ & -0.002 & -0.07 \\
\hline & $R^{2}$ & \multicolumn{2}{|c|}{.30} & \multicolumn{2}{|c|}{.03} & \multicolumn{2}{|c|}{02} \\
\hline & $F$ & \multicolumn{2}{|c|}{22.79} & \multicolumn{2}{|c|}{20.81} & \multicolumn{2}{|c|}{12.83} \\
\hline & Sig. & \multicolumn{2}{|c|}{.000} & \multicolumn{2}{|c|}{.000} & \multicolumn{2}{|c|}{.000} \\
\hline
\end{tabular}

$* P<0.01$

Three regression models were createdin order to test the hypotheses. In these models, workload and responsibility load were considered independent variables. The dependent variables were workload in Model 1, emotional commitment in Model 2, and turnover intention in Model 3. All three models were found to be statistically significant. 
In the conducted correlation analysis, a positive effect was found which presented the relationship condition between the dependent variables of workload and responsibility load. Therefore, $\mathrm{H}_{1}$ is supported.

Of the independent variables in Model 1, both workload and responsibility affected work stress. Thus, $\mathrm{H}_{2 \mathrm{a}}$ and $\mathrm{H}_{2 \mathrm{~b}}$ are supported. Of the independent variables in Model 2, both workload and responsibility load affected emotional commitment. Therefore, $\mathrm{H}_{3 \mathrm{a}}$ and $\mathrm{H}_{3 \mathrm{~b}}$ are both supported. Furthermore, of the independent variables in Model 3, workload affected turnover intention, while responsibility load had no effect on it. Thus, while $\mathrm{H}_{4 a}$ is supported and $\mathrm{H}_{4 \mathrm{~b}}$ is rejected.

\section{Discussion and Conclusion}

In the current study, we analyzed the effects of both workload and responsibility load on work stress, emotional commitment, and turnover intention. A positive relationship was found between workload and responsibility load. According to this result, when the workload of academics increases, their responsibilities increase as well. An increased workload is due to additional administrative and individual responsibilities apart from their educational and training duties.

At the end of the regression analysis, a positive relationship is found between workload and work stress. This result is in accordance with those of previous literature, where it was found that academics with a high workload also report high levels of stress.

It appears that workload has a relationship with emotional commitment. In our research, we found that emotional commitment decreases when the workload increases. This result is consistent with that of previous studies, where it was found out that workload negatively affects organizational commitment (Maxwell \& Steele, 2003; Rayton, 2006). Thus, the workload of academics reduces their emotional commitment to the organization.

We found that workload has a positive effect on turnover intention. Various studies have shown that workload increases turnover intention (Jones et al., 2007). Our results revealed that the turnover intention of academics with a high workload, especially those who have administrative responsibilities as well, increases due to the addition of administrative load to their current workload.

There is a positive relationship between the responsibility load and work stress. Various studies show a positive relationship between responsibilities and stress (Markham, 1989). Thus, the stress level of academics increases due to responsibility load.

We found that there is a positive relationship between responsibility load and emotional commitment, which is in accordance with previous literature claiming that a relationship between responsibility and commitment exist (Chow, 1994; Meyer \& Allen, 1991). In our study, the emotional commitment between an individual and an organization are understood due to the given responsibilities. In addition, we see that taking responsibility makes an individual feel like she/he is part of the organization.

We found that responsibility load has no effect on turnover intention. This condition shows that even though administrative load responsibilities increase stress levels, they do not increase turnover intention in academics. 
A significant element of our study is the use of a responsibility load variable consisting of five questions. In the present research, we see that this newly created scale has a meaningful relationship with the other independent variables studied. Our analysis of workload and responsibility load with the variables of work stress, emotional commitment, and turnover intention will direct future research conducted on this subject. Thus, it can act as an example for new studies that put forth the relationship between responsibility load, as seen in this study, and organizational attitude, which is not addressed in the current study. High participation gives our study substance and it will be helpful for further research on similar subjects.

The study is also limited since it is comprised of academicians working in state universities. Another limitation is the legal status of the academicians, especially because of their performance that does not affect their salary. For studies conducted in academia, results can vary due to the inability to provide homogeneity.

\section{References}

Adams, N. (1988). Occupational stress and workplace stresses: Identifying and ameliorating the stresses. Ergonomics International, 88, 514-516.

Arnold, H. J., \& Feldman, D. C. (1982). A multivariate analysis of the determinants of job turnover. Journal of Applied Psychology, 67(3), 350-360.

Bayram, L. (2005). Yönetimde yeni bir paradigma: Örgütsel bağl1lık. Sayıştay Dergisi,59, 125-139.

Bluedorn, A. C. (1982). A unified model of turnover from organizations. Human Relations, 35, 135-153.

Boyle, G. J., Borg, M. G., Falzon J. M., \& Baglioni, A. J. Jr. (1995). A structural model of the dimensions of teacher stress. British Journal Educational Psychology, 65(1), 49-67.

Brennan, D. S., \& Spencer, A. J. (2010). Responsibility loadings for dental services by general dentists. BMC Health Services Research, 10(177), 1-6.

Britt, T. W. (1999). Engaging the self in the field: Testing the triangle model of responsibility. Personality \& Social Psychology Bulletin, 25(6), 698-708.

Brown, B. B. (2003). Employees' organizational commitment and their perception of supervisors' relations-oriented and taskoriented leadership behaviors (Unpublished doctoral dissertation). Virginia: Virginia Polytechnic Institute and State University.

Calder, B. J., Philips, L. W.,\& Tybout, A. M. (1981). Designing research for application. Journal of Consumer Research,8(2), 197-207.

Cedoline, A. J. (1982). Job burnout in public education: Symptoms, causes, and survival skills. New York: Teacher's College Press.

Chan, K. B., Lai, G., Ko, Y. C., \&Boey K. W. (2000). Work stress among six professional groups: The Singapore experience. Social Science Medicine, 50(10), 1415-1432.

Chow, I. H. S. (1994). Organizational commitment and career development of Chinese managers in Hong Kong and Taiwan. The International Journal of Career Management, 6(4), 3-9.

Daniels, K., Harris, C., \& Briner, R. B. (2004). Linking work conditions to unpleasant affect: Cognition, categorisation, and goals. Journal of Occupational \& Organizational Psychology, 77(3), 343-364.

Egan, T. M., Yang, B., \& Bartlett, K. R. (2004). The effects of organizational learning culture and job satisfaction on motivation to transfer learning and turnover intention. Human Resource Development Quarterly, 15(3), 279-301.

Erat, S. (2012). Örgütlerde algılar, roller ve yüklerin, örgütsel stres ve çalışan sonuçlarına etkisi, üniversitelerde bir uygulama (Unpublished doctoral dissertation). Yayımlanmamış Doktora Tezi, Gebze Yüksek Teknoloji Enstitüsü, Gebze.

Fried, Y., Grant, A. M., Levi, A. S., Hadani M., \&Slowik, L. H. (2007). Job design in temporal context: A career dynamics perspective. Journal of Organizational Behavior 28(7), 911-927.

Greenberg, J., \& Baron, R. A. (1995). Behaviour in organizations: Understanding and managing the human side of work. Upper Saddle River, NJ: Pearson Education, Inc. 
Guay, R. P., Oh, I. S., Choi, D., Mitchell, M. S., Mount, M. K., \& Shin, K. H. (2016). Why people harm the organization and its members: Relationships among personality, organizational commitment, and workplace deviance.Human Performance, $29,1-15$.

Hancock, P. A. (1989). The effect of performance failure and task demand on the perception of mental workload. Applied Ergonomics, 20(3), 197-205.

Hollenbeck, J. R., \& Williams, C. R. (1986). Turnover functionality versus turnover frequency: A note on work attitudes and organizational effectiveness. Journal of Applied Psychology, 71(4), 606-611.

House, A. J. S., \& Rizzo, J. R. (1972). Role conflict and ambiguity as critical variables in model of organizational behaviour. Organizational Behaviour \& Human Performance, 7, 467-505.

Jones, E., Chonko, L., Rangarajan, D., \& Roberts, J. (2007). The role of overload on job attitudes, turnover intentions, and salesperson performance. Journal of Business Research, 60(7), 663-671.

Jung, H. S., \& Jung, H. S. (2001). Establishment of overall workload assessment technique for various tasks and workplaces. International Journal of Industrial Ergonomics, 28(6), 341-353.

Kaya, N., \& Selçuk, S. (2007). Bireysel başarı güdüsü organizasyonel bağlılığı nasıl etkiler? Doğuş Üniversitesi Dergisi, 8(2), $175-190$.

Kirmeyer, S. L., \& Dougherty, T. W. (1988). Workload, tension, and coping: Moderating effects of supervisor support. Personnel Psychology, 41(1), 125-139.

Kreitner, R., \& Kinicki, A. (1998). Organizational behaviour (4 ${ }^{\text {th }}$ ed.). Boston, Massachusetts: Irwin McGraw-Hill.

Kwon, K., Bar, J., \& Lawler, J. J. (2010). High commitment HR practices and top performers: Impact on organizational commitment. Management International Review, 50, 57-80.

Lambert, E. G., Hogan, N. L., \& Griffin, M. L. (2007). The impact of distributive and procedural justice on correctional staff job stress, job satisfaction, and organizational commitment. Journal of Criminal Justice, 35(6), 644-656.

Lazarus, R. S. (1993). From psychological stress to the emotions: A history of changing outlooks. Annual Review of Psychology, 44, 1-21.

Lee, J. S., Joo, E. J., \& Choi, K. S. (2013). Perceived stress and self-esteem mediate the effects of work-related stress on depression. Stress \& Health, 29(1),75-81.

Lim, V. K. G., \& Teo, T. S. H. (1999). Occupational stress and IT personnel in Singapore: factorial dimensions and differential effects. International Journal of Information Management, 19(4), 277-291.

Liou, S. R., \& Cheng, C. Y. (2010). Organisational climate, organisational commitment and intention to leave amongst hospital nurses in Taiwan. Journal of Clinical Nursing, 19(11/12), 1635-1644.

Markham, U. (1989). Managing stress: The practical guide to using stress positively. Dorset: Element Books Ltd.

Maslach, C., Schaufeli, W. B., \& Leiter, M. P. (2001). Job burnout. Annual Review of Psychology, 52, 397-422.

Matteson, M. T., \& Ivancevich, J. M. (1987). Controlling work stress: Effective human resource and management strategies. San Francisco, CA: Jossey-Bass

Maxwell, G., \& Steele, G. (2003). Organizational commitment: A study of managers in hotels. International Journal of Contemporary Hospitality Management, 15(7), 362-369.

Meyer, J. P., \& Allen, N. J. (1991). A three-component conceptualization of organizational commitment. Human Resources Management Review, 1,61-89.

Meyer, J. P., \& Allen, N. J. (1997). Commitment in workplace, theory, research and application. Thousand Oaks, Calif: Sage Publications.

Meyer, J. P., \& Herscovitch, L. (2001). Commitment in the workplace toward a general model, Human Resource Management Review, 11, 299-326.

Meyer, J. P., Stanley, D. J., Herscovitch, L., \& Topolnytsky, L. (2002). Affective, continuance, and normative commitment to the organisation: A meta-analysis of antecedents, correlates, and consequences. Journal of Vocational Behavior, 61, 20-52.

Moon, T. W., Hur, W. M., Ko, S. H., Kim, J. W., \& Yoon, S. W. (2014). Bridging corporate social responsibility and compassion at work: Relations to organizational justice and affective organizational commitment. Career Development International, 19(1), 49-72.

Nasurdin, A. M., Ramayah, T., \& Kumaresan, S. (2005). Organizational stressors and job stress among managers: The moderating role of neuroticism.Singapore Management Review, 27(2), 63-79.

Nunually, J. C. (1978). Psychometric theory. New York, NY: McGraw Hill. 
O’Neill, J. W., \& Davis, K. (2011). Work stress and well-being in the hotel industry. International Journal of Hospitality Management, 30(2), 385-390.

Paşa, M. (2007). Stresin bireysel performans üzerindeki etkileri ve bir uygulama.Uludağ Üniversitesi Sosyal Bilimler Enstitüsü, Yayınlanmamış Doktora Tezi, Bursa.

Paulse, J. (2005). Sources of occupational stress for teachers, with specific reference to the inclusive education model in the Western Cape (Unpublished master's thesis). University of the Western Cape, South Africa.

Randall, L. (2006). Enhancing the academic life of the mid-career professional. Senate Forum, 22(1), 1-20.

Rayton, B. A. (2006). Examining the interconnection of job satisfaction and organizational commitment: An application of the bivariate probit model. International Journal of Human Resource Management, 17(1), 139-154.

Sanders, M. S., \& McCormick, E. J. (1987). Human factors in engineering and design. New York: McGraw-Hill.

Sax, L. J., Gilmartin S. K., \& Bryant, A. N. (2003). Assessing response rates and non-response bias in web and paper surveys. Research in Higher Education, 44(4), 409-431.

Schonlau, M., Fricker, R., \& Elliott, M. (2002). Conducting research surveys via e-mail and the web. Santa Monica, CA: RAND.

Sigler, R. T., \& Wilson, C. N. (1988). Stress in the work place: Comparing police stress with teacher stress. Journal of Police Science \& Administration, 16(3), 151-162.

Steers, R. (1981). Introduction to organizational behaviour. Glenview, IL: Scott-Foresman.

Stevens, J. M., Beyer, J. M., \& Trice, H. M. (1978). Assessing personal, role, and organizational predictors of managerial commitment. Academy of Management Journal. 21(3),380-396.

Tel, M., \& Köksalan, B. (2008). Öğretim Üyelerinin Spor Etkinliklerinin Sosyolojik Olarak İncelenmesi (Doğu Anadolu Örneği). Firat Üniversitesi Sosyal Bilimler Dergisi, 18(1),261-278.

Tett, R. P., \& Meyer, J. P. (1993). Job satisfaction, organizational commitment, turnover intention, and turnover: Path analysis based on meta-analytic findings. Personnel Psychology, 46(2), 259-293.

Torka, N., Schyns, B., \& Looise, J. K. (2010). Direct participation quality and organisational commitment: The role of leadermember-exchange. Employee Relations, 32(4), 418-434.

Ünalan, D., Çetinkaya, F., Özyurt, Ö., \& Kayabaşı, A. (2006). Bir üniversite hastanesinde çalışan sekreterlerde iş memnuniyeti. Hacettepe Sağlık İdaresi Dergisi, 9(1), 1-18.

Villanueva, D., \& Djurkovic, N. (2009). Occupational stress and intention to leave among employees in small and medium enterprises, International Journal of Stress Management, 16(2), 124-137.

Weiner, J. S. (1982). The measurement of human workload. Ergonomics, 25(11), 953-965.

Yaprak, E. (2009). Hemşirelerin işten ayrılma niyetlerini belirleyen faktörler: Örgüt iklimi, sosyo-demografik ve çalışma özellikleri (Unpublished doctoral dissertation).Yayınlanmamış Doktora Tezi, Dokuz Eylül Üniversitesi, Sağlık Bilimleri Enstitüsü, İzmir.

Yıldırım, A., Ünal, A., \& Çelik, M. (2011). Öğretmen kavramına ilişkin öğretmen, yönetici ve müfettiş algılarının analizi. Uluslararası Insan Bilimleri Dergisi.8(2),92-109. 